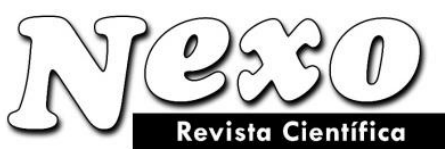

Vol. 34, No. 04, pp. 1215-1230/Septiembre 2021
ISSN-E 1995-9516

Universidad Nacional de Ingeniería COPYRIGHT @ (UNI). TODOS LOS DERECHOS RESERVADOS

http://revistas.uni.edu.ni/index.php/Nexo https://doi.org/10.5377/nexo.v34i04.12650

\title{
Exploration a New Model for Assessment the Environmental Risk of Dams in Construction Stage (Case Study: Balarood Dam, Khuzestan)
}

\section{Exploración de un Nuevo Modelo para Evaluar el Riesgo Ambiental de las Represas en la Etapa de Construcción (Estudio de caso: Represa Balarood, Khuzestan)}

\author{
Farzaneh Movahednejad \\ Department of Engineering, Science and Research Branch, Islamic Azad University, Tehran, \\ Iran \\ *Movahednejadfarzaneh@gmail.com
}

(recibido/received: 15-mayo-2021; aceptado/accepted: 01-agosto-2021)

\begin{abstract}
Dam projects have serious influences on environmental parameters; therefore, environment risk assessment of dam is one of the most significant aspects of environmental risk management in these projects. The present study was conducted with the aim of presenting a new model for assessing the environmental risk of dams in construction stage. After identifying environmental risks and using the EFMEA method, the risk priority number for each of the environmental aspects was calculated and classified. Then, to assess and prioritize the identified environmental risks, the VIKOR method was used. The results showed that in The EFMEA method and by comparing calculated risk numbers, the risk of water pollution of Balarood River with the risk priority number of 125 is in the first priority. In the VIKOR method, the risks of water pollution in terms of agreement (high, average, low) with weights $(1,300,1,000$ and 0,700$)$ were identified as the most important risks. In the present article, using EFMEA and VIKOR methods in the environmental risk assessment of the dam, the most important risks were determined. The most important proposed corrective measure to reduce the environmental risks is the construction and completion of wastewater treatment for industrial units.
\end{abstract}

Keywords: Environmental Risk, VIKOR Model, Construction stage, Dam.

\section{RESUMEN}

Los proyectos de represas tienen serias influencias sobre los parámetros ambientales; por lo tanto, la evaluación del riesgo ambiental de la presa es uno de los aspectos más significativos de la gestión del riesgo ambiental en estos proyectos. El presente estudio se realizó con el objetivo de presentar un nuevo modelo de evaluación del riesgo ambiental de presas en etapa de construcción. Después de identificar los riesgos ambientales y utilizar el método EFMEA, se calculó y clasificó el número de prioridad de riesgo para cada uno de los aspectos ambientales. Luego, para evaluar y priorizar los riesgos ambientales identificados, se utilizó el método VIKOR. Los resultados mostraron que en el método EFMEA y al comparar los números de riesgo calculados, el riesgo de contaminación del agua del río Balarood con el número de prioridad de riesgo de 125 es la primera prioridad. En el método VIKOR, los riesgos de 
contaminación del agua en términos de concordancia (alto, medio, bajo) con los pesos (1300, 1000 y 0,700) se identificaron como los riesgos más importantes. En el presente artículo, utilizando los métodos EFMEA y VIKOR en la evaluación del riesgo ambiental de la presa, se determinaron los riesgos más importantes. La medida correctiva propuesta más importante para reducir los riesgos ambientales es la construcción y finalización del tratamiento de aguas residuales para unidades industriales.

Palabras clave: Riesgo Ambiental, Modelo VIKOR, Etapa de Construcción, Presa.

\section{INTRODUCTION}

Since the dam projects have serious impacts on environmental parameters, it is possible that real identified impacts in post-assessment environmental impact studies differs from the predicted results in the environmental impact assessment report (EIA) of the dams (Chen, et al., 2014). If there is difference between the real identified impacts in post-assessment studies of environmental impacts and predicted impacts in the EIA report, use of it to justify the environment protection plan and confirming predicted results became possible. Therefore, the quality of the environment after completion of the project is frequently assessed and, as a result, appropriate corrective measures is suggested (Dipper, et al.,2010; Wang et al.,2012). Conducting environmental post-assessment impact studies is necessary for construction projects affecting the area. Since the EIA conducts early in the work, it is possible to not accurately predict environmental impacts over a long period of time (Morales-Torres, et al.,2016). Post-assessment refers to the validity or accuracy of the dam construction, corrective measures in the surrounding environment and monitoring that measures to preserve the sustainable development of dams (Shayna, et al.,2017). Construction of large dams has great environmental, biological, sanitary, social and economic impacts on surronding environment (Raei, et al.,2020). Constructing dam is a civil and relatively longstanding activity that human beings have been doing for a long time, for providing, controlling and directing water resources. In according to the growth and development of dam construction in the world, especially in Iran, study of the environmental impacts of the dam is of particular importance. Therefore, considering that dam projects have potential risks on their surroundings in the construction operation as well as in the exploitation phase, in post-assessment studies, environmental impacts, risk creator factors and the resulting risks of projects should be identified and proposed the measures to minimize these risks. Environmental impact assessment of dams is a tool of this work. Environmental risk assessment is a step beyond risk assessment and in addition to examining and analyzing various aspects of risk, while fully recognizing the environment of the affected area, considers the sensitivity of the affected environment and also the specific environmental values of the region in the analysis and risk assessment (Wang, et al.,2012). Environmental risk assessment is a legal requirement for activities that have the potential to damage human health or environment (Zhang, et al.,2012). Some of the most important studies of environmental post-assessment impacts and dam risk assessment will be refers below (Samaras, et al.,2020).

\section{MATERIALS AND METHODS}

The objective of this study is to develop a new model for assessing the environmental risk of dams during studies of environmental post-assessment impacts in the construction stage of Balarood Dam in Khuzestan. First, to identify the risks of the project, according to the studies conducted in the field of dams risk in the world and Iran and based on technical and environmental studies and collecting basic information and also by conducting a field visit to the Balarood Dam project in Khuzestan and interviewing environmental experts and professors we reviewed the results of experiments on the most important physical and chemical parameters. In the study area, we first identified and assessed the environmental aspects using the environmental failure modes of analysis technique and environmental effects (EFMEA). 


\section{RESULTS AND DISCUSSION}

\subsection{Theoretical Framework}

As mentioned in the introduction, environmental risk assessment is a step beyond risk assessment. Analysis and risk assessment of the area, in addition to examining and analyzing various aspects of risk, completely recognizes the environment of affected regional as well as the sensitivity of the environment and the specific values of area's environment. This framework for the use of integrated methods is of significant importance. In the Wang and et al. (2012) view, the real impacts of projects after the construction phase are reviewed in the post-assessment process, an appropriate platform for comparing the results predicted in the EIA and the actual results provided. The difference between these results helps the validity and accuracy measurement of the predictions obtained from the EIA process; it is also possible to assess the quality of the environment after the completion of project. In this study, post methods and concepts are reviewed and, as a result, a proper reference for environmental management of dam construction projects is provided. Samaras et al. (2020) studied the risks of three dams in Greece in the exploitation phase using the AHP method of hierarchical analysis and ELECTRE (multi-indicator decision-making method). They were able to identify the risk of interior erosion in two dams. Chen et al (2014) examined possible risks due to construction of Gavi dam in Ilam province using MIKE-11 model and TOPSIS method. Using the MIKE-11model, they simulated the flood zone and concluded that in the studied watershed, risks of habitat degradation, water pollution and its effects on aquatic animals are at the highest level. Dipper et al (2010) for assessing environmental risk of Alavian Dam, used fuzzy multiple decision ranking method. The results of this study showed that the "Design Error" is the highest level of risk and "Earthquake" has the lowest level of risk. Wang et al. (2012) in its study on environmental risk assessment of gas power plants in southern Iran, identified risk factors and according to the severity and probability of occurrence and extent of pollution, by EFMEA method assessed the risks. They are for the improvement of EFMEA technique, used EFMEA and TOPSIS method. In their research, explosion and gas leakage identified as the most important risks.

This study is conducted with the aim of presenting a new model for assessment of environmental risk of dams in construction stage, using integrated methods of VIKOR \& EFMEA (case study of Balarood Dam Khuzestan).

Then, we weighted environmental risks identified in the follow-up phase based on the criteria of severity, probability of occurrence and extent of pollution by using entropy method. In the next step, according to the multi-indicator decision-making methods in different projects and with considering the features of dam and environment affected and types of environmental risks arising from the project, in analysis and assessment of environmental risks, the consensual and optimization multi-criteria (VIKOR) technique were used that is a multi-criteria decision making method to solve the discrete decision making problem. Multi-indicator models are used to select an option from the limited options. Each of the EFMEA and VIKOR methods are explained respectively, in this text. Figure 1 shows execution process of Balarood Dam risk assessment in post-assessment studies of environmental impacts in this research. 


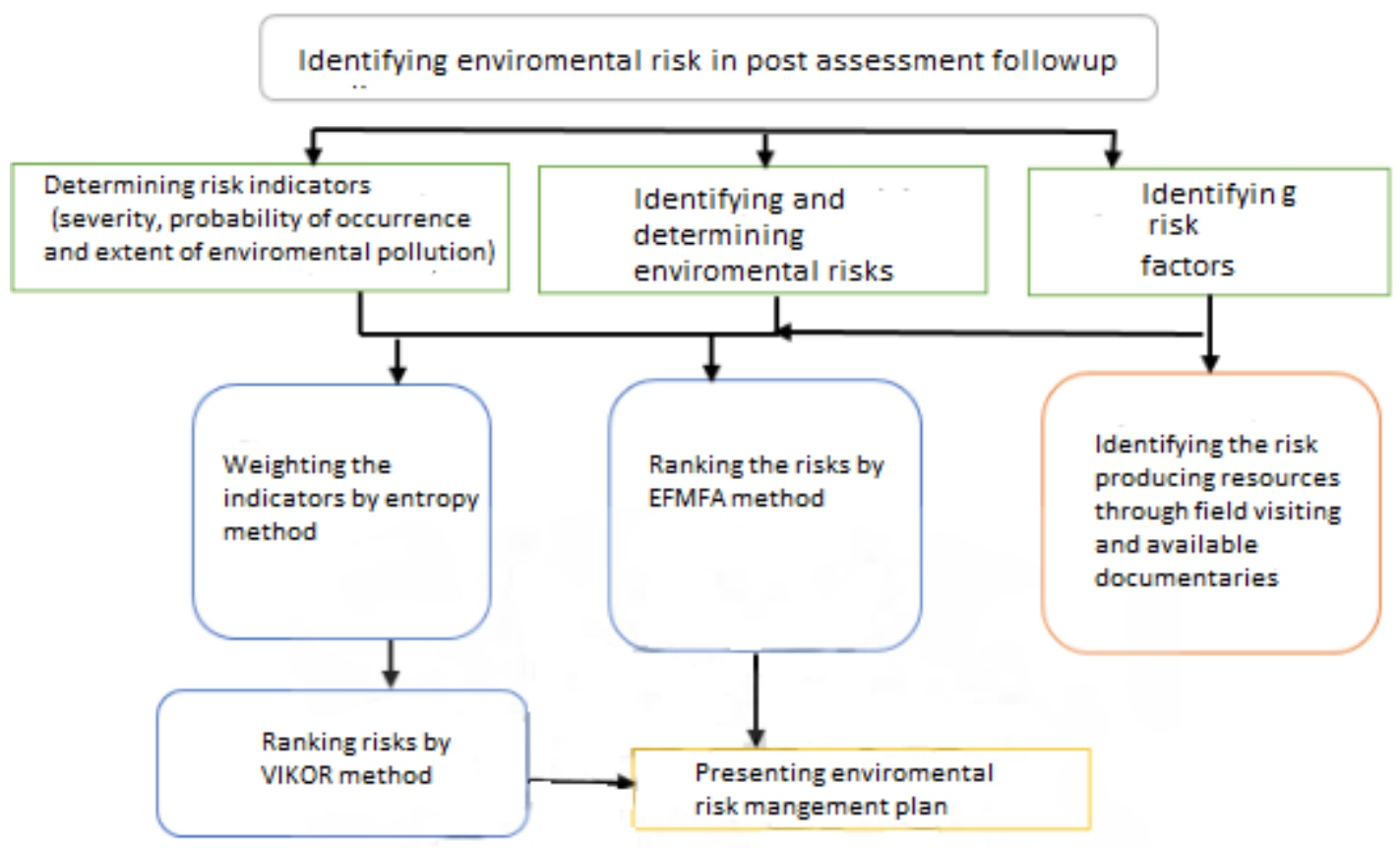

Figure 1: Execution process of Balarood Dam risk assessment in post-assessment studies

\subsection{Experiments Performed in the Environmental Section of Balarood Dam (Studied Region)}

Construction site of Balarood Reservoir Dam in Khuzestan, is located between Andimeshk and Hosseinieh, longitude $48^{\prime}$ and $15^{\prime}$ to $48^{\prime}$ and $20^{\prime}$ eastern, as well as latitudes $32^{\prime}$ and 38 to $32^{\prime}$ and $45^{\prime}$ northern, about $25 \mathrm{~km}$ away from Andimeshk, on the Balarood River from its tributaries of The Dez River. Surface water resources in the study area are Dez and Balarood Rivers. This dam is constructing with the aims of controlling the floods of Balarood River, reduce floods of Dez River and water supply of about 6990 hectares of agricultural land. Production of $11.5 \mathrm{GWh}$ per year of hydropower and environmental protection condition of downstream of the dam are other goals of Balarood Dam. Operations and activities of Balarood Reservoir Dam are taking place in two stages of preparation, infrastructure and execution (construction) measures. Table 1 shows some technical specifications of the dam and Figure 2 shows the geographical location of the study area.

Table 1: Technical specifications of the dam

\begin{tabular}{|c|c|}
\hline Type of dam & Earthen with vertical clay core \\
\hline The length of crest & 1070 meters \\
\hline The width of crest & 10 meters \\
\hline Height from the river floor & $75 / 5$ meters \\
\hline Height from the foot & $77 / 5$ meters \\
\hline The total volume of the reservoir & 131 million cubic meters \\
\hline The 50-year sediment volume & $39 / 52$ million cubic meters \\
\hline
\end{tabular}




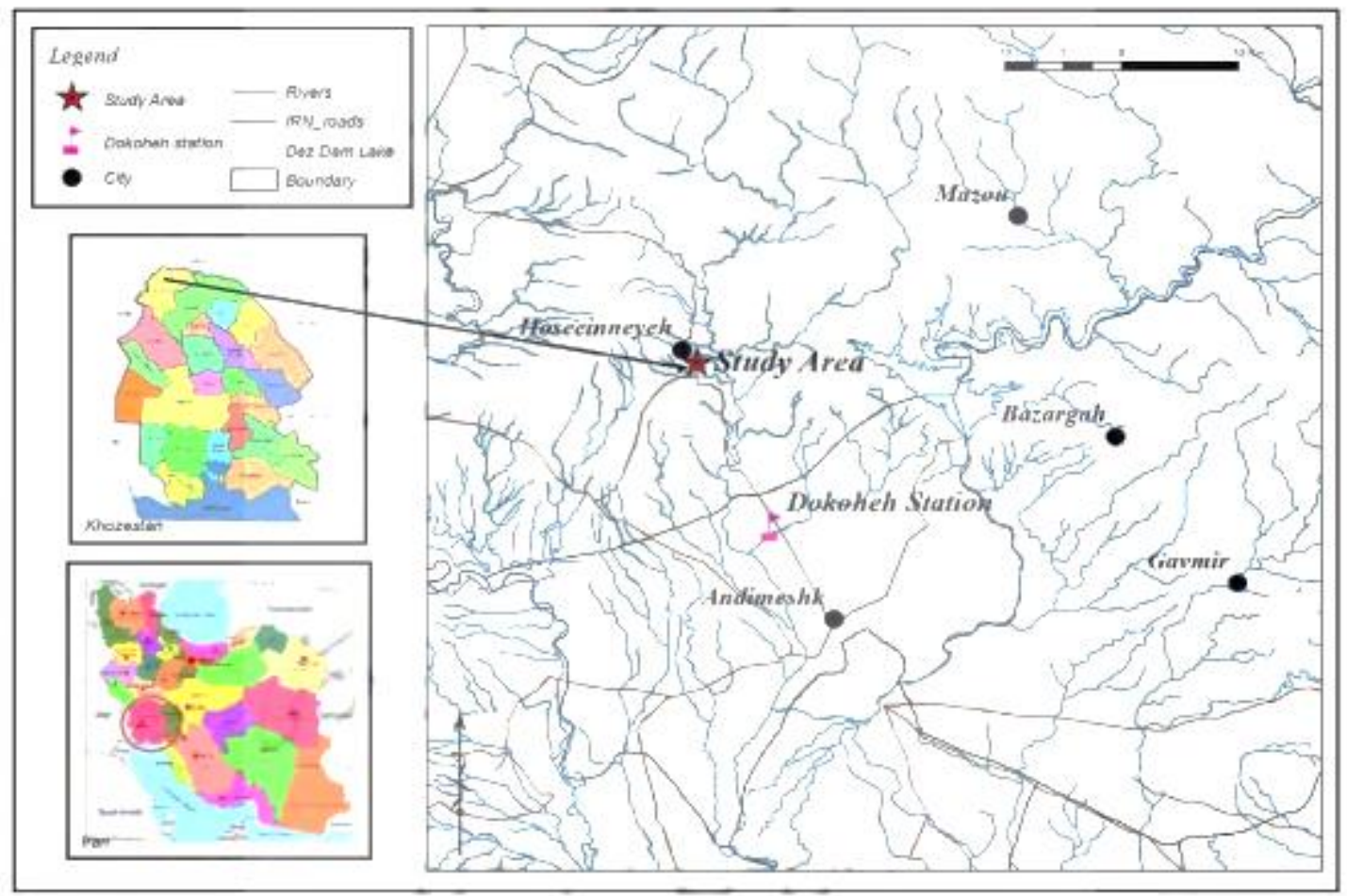

Figure 2: The location of the study area

In this study, in order to identify the most important environmental risks of Balarood Dam in Khuzestan, we examined the parameters of air quality, water and noise.

Undoubtedly, during the construction phase, a major change in the water quality of the river due to the increase in speed and bed dredging will occur up to a distance from the river and water quality (especially in terms of turbidity) will be reduced. To study the chemical quality of Balarood River water in the regional online station (Dokuheh Station), using titration, reflux, gravimetric, photometric and atomic absorption methods, we examined total dissolved solids and electrical conductivity during the years 2010 to 2018 as well as the amount of biochemical oxygen demand, chemical oxygen demand and fecal coliforms. In the construction phase, according to the excavation operations and embankment, there is definitely a lot of dust and due to relatively heavy fuel consumption in machinery, in addition to dust, large amounts of $\mathrm{SO}^{2}$, smoke, $\mathrm{CO}$ and particulate matter are generated during construction operations. Therefore, the Hivol pump made in England and the gravimeter method as well as LSI device, respectively used to measure particulate matter and gaseous pollutants. We conducted these experiments in 2010, through the local method by sampling in eight locations of the study area. We selected exhaust outlet, machinery and outlet of the tunnel opening as the sampling site. We checked noise pollution rate with Cell 4-40 sound meter made by Casllacell in England and with standard IEC651.1979 for the workshop environment and the construction site of the tunnel in eight main directions (northern side end, south, east, west, northwest, northeast, and southwest, southeast) and at a distance of 40 kilometers of equipment. Status of sound pressure level and noise pollution was calculated using the method assessment of equivalent level in weight network A for 30 minutes (approved by Article 2 of the executive regulations of noise pollution prevention). 


\subsection{Ranking the Environmental Risks}

\subsubsection{Method of Failure Modes Analysis and Environmental Effects of EFMEA}

We conducted preliminary studies and data collection related to Balarood Dam through field visit, interview with experts stationed in the facilities and health and safety executive experts. After obtaining the agents of final risk, to illustrate the risks, we provided a worksheet for the construction phase in the analysis technique of failure modes and environmental impacts (EFMEA). EFMEA is one of the failure modes and effects analysis trends techniques and it is used in open environments, instead of using probability of discovery (specific to indoor environments and safety risks) the extent of pollution factor is used, which is more suitable for environmental risks. This component is applied in intensity and probability of occurrence (Table 5.) This worksheet is reviewed by professors and experts and they confirmed its content review and validity. To check the reliability of the tool, first with a pre-test, we provided a questionnaire to 30 people. Then, the reliability of the questionnaire with using Cronbach's alpha coefficient calculated, that the coefficient obtained was 0.92 and shows high level of reliability. In this study, we used the EFMEA technique that promotes FMEA process efficiency by solving two very important problems, including risk prioritization number and comparison of corrective measures. In general, the EFMEA process provides a basis for selection of optimal corrective measure. Also, this process allows the execution of an action and the amount of risk prioritization number expected after its implementation. EFMEA considers both probability of success (e.g., reduction of risk prioritization number) and adverse impacts of occurrence probability (on people, system, product, process or environment) causes by the implementation of corrective measures (Bluvband \& et-al, 2004:3451). Then each of the degrees of severity, probability of occurrence and extent of pollution according to Tables 2 to 4 obtained. Degree of intensity means estimating the seriousness of the effect, the probability of occurrence is the timing frequency of the occurrence of environmental aspects and their consequences and the extent of pollution means considering scope and spread of pollution. The scoring method was such that each of the indicators scored 1 to 5; so that in the most severe cases, the score is 5 and in the least cases, 1 score was awarded to the desired parameter. Then, we set scores for each risk. Therefore, risk priority number multiplied by three factors of severity, probability of occurrence and extent of pollution for all risks:

\section{Extent of pollution $\times$ probability of occurrence $\times$ severity $=$ risk priority number}

Next, we calculated the range of the category. First we calculated the number of categories with the following formula and obtained the length of the category from the difference between the smallest value and the largest value of the risk priority number over the number of categories. Then, we determined the level of environmental risk of each activity. Aspects of that their risk priority number is high considered as critical activities that are needed corrective measures.

$$
\begin{aligned}
& \text { Categories Number }=1+3.3 \text { Logn } \\
& \text { Category length }=\frac{\text { Lowest Risk Priority Number }- \text { Lowest Risk Priority Number }}{\text { Category Number }}
\end{aligned}
$$

Table 2: EFMEA intensity ranking (Gati., et al, 2012)

\begin{tabular}{|c|c|c|}
\hline Intensity & Intensity description & Score \\
\hline Extreme / catastrophic & $\begin{array}{c}\text { Very harmful or potentially } \\
\text { destructive/ wasting or too much } \\
\text { resources consuming }\end{array}$ & 5 \\
\hline Serious & $\begin{array}{c}\text { harmful but not potentially } \\
\text { destructive/ wasting or much } \\
\text { resources consuming }\end{array}$ & 4 \\
\hline Average & $\begin{array}{c}\text { Relatively harmful/ waste or } \\
\text { average consumption of resources }\end{array}$ & 3 \\
\hline
\end{tabular}




\begin{tabular}{|c|c|c|}
\hline Low & $\begin{array}{c}\text { Low potential harmful/ waste or } \\
\text { low consumption of resources }\end{array}$ & 2 \\
\hline Less harmful & $\begin{array}{c}\text { It is less harmful and negligible/ } \\
\text { waste or less consumption of } \\
\text { resources }\end{array}$ & 1 \\
\hline
\end{tabular}

Table 3: EFMEA probability of occurrence ranking (Ibid)

\begin{tabular}{|c|c|}
\hline Probability of occurrence & Score \\
\hline $\begin{array}{l}\text { A very frequent and certain event (it may occurs } \\
\text { every day) }\end{array}$ & 5 \\
\hline A common event (it may occurs during the week) & 4 \\
\hline $\begin{array}{c}\text { A probable and average event (it may occurs } \\
\text { during the month) }\end{array}$ & 3 \\
\hline A Low event (it may occurs once a year) & 2 \\
\hline $\begin{array}{c}\text { An impossible and unlikely event (it may occurs } \\
\text { once every } 10 \text { years) }\end{array}$ & 1 \\
\hline
\end{tabular}

Table 4: EFMEA pollution extent ranking (Ibid)

\begin{tabular}{|c|c|}
\hline Pollution extent & Score \\
\hline Regional & 5 \\
\hline At the project level & 4 \\
\hline At the workshop level & 3 \\
\hline At the unit level & 2 \\
\hline At the workstation level & 1 \\
\hline
\end{tabular}

\subsubsection{VIKOR Multi-Criteria Optimization and Agreement Strategy Technique}

In this study, after identifying environmental risks in order to rank the identified risks by VIKOR technique, first with the entropy method we weighted risk factors of Balarood Dam in four steps as follows. Entropy method is one of the most widely used multi-indicator decision-making methods that are used to calculate the weight of criteria; this method is an auxiliary method. Entropy in information theory is a measure of uncertainty expressed by a discrete probability distribution; therefore, the greater the fluctuations in the indicating values, the more important that indicator will be and the coefficient of importance (weight) will be higher. In this method, the weight of the criteria is calculated by forming a matrix, which its rows create options of research and its columns the criteria of research.

$$
\begin{aligned}
& \text { Step 1: Calculation of } \mathrm{P}_{\mathrm{ij}} \\
& \qquad \mathrm{P}_{\mathrm{ji}}=\frac{a i j}{\sum_{i=1}^{m} a i j}
\end{aligned}
$$

Step 2: Calculation of entropy value $\mathrm{E}_{\mathrm{j}}$

$$
\mathrm{Ej}=-\mathrm{K} \sum_{i=1}^{m}[p i j \ln p i j] ; \forall j
$$

Step 3: Calculation of uncertainty value dij

$$
\mathrm{dij}=1-\mathrm{Ej} ; \forall \mathrm{j}
$$

Step 4: Calculation of weights $\mathrm{W}_{\mathrm{j}}$

$$
W j=\frac{\mathrm{dj}}{\mathrm{d} \sum_{n} j=\mathrm{dj}} ; \forall \mathrm{j}
$$


According to the study of multi-criteria decision making methods in similar projects and with considering the dam features and environmental under its influence, VIKOR method as a quantitative approach due to factors such as understanding, valuing decision makers, more credibility and flexibility as well as combining large volumes of indicators has the ability to provide an overview of an activity or a set of criteria. VIKOR method concentrates on selection from a set of options and their rankings and determination of compatible solutions on an issue with challenging criteria that may help decision makers to the make a final decision. It is due to the use of indicator $\mathrm{V}$ and collective agreement has better optimization in decision making. This is the advantage of this method compared to others multi-criteria decision-making methods. Therefore, we used this method to prioritize and analyze dam risks. VIKOR method is created to solve multi-criteria decision-making problems with conflicting or non-measurable criteria. The effectiveness of this method is most evident when the decision maker cannot express his own preferences and uses this method to provide consensual solutions of problem solving. Consensual solution is a justified solution that is close to the ideal answer and because it is contains maximum group desirability and least individual regret; decision makers accept it. We assessed identified risks based on criteria of severity, probability of occurrence and the extent of pollution using the VIKOR method. We gave a score of 1 to 5 to each of the mentioned criteria on the scale of the EFMEA method. The most severe cases received a score of 5 and the least severe cases received a score of 1 . Method steps in a multicriteria decision-making problem, with $\mathrm{n}$ criteria and $\mathrm{m}$ option are as follows.

Step 1: Forming a decision matrix

Step 2: Determine the weight vector of the criteria, which is defined using the entropy method of weights $\mathrm{W}=\left(\mathrm{W}_{1}, \mathrm{~W}_{2}, \ldots, \mathrm{W}_{\mathrm{n}}\right)$

Step 3: Determine the positive and negative ideal points

$$
\begin{aligned}
& \mathrm{f}^{+}=\operatorname{Max} \mathrm{f}_{\text {ii }} \\
& \mathrm{f}^{-}=\operatorname{Min} \mathrm{f}_{\text {ij }}
\end{aligned}
$$

Step 4: Calculate the amount of usefulness and uncertainty of the criteria for each option

$$
\begin{gathered}
\mathrm{S}_{\mathrm{i}}=\sum_{j=1}^{n} W \times \frac{f^{*}-f_{i j}}{f^{*}-f^{-}} \\
\operatorname{RiMax}=\left[W_{j} \times \frac{f^{*}-f_{i j}}{f^{*}-f^{-}}\right]
\end{gathered}
$$

Step 5: Calculate the Vicor indicator for each options

$$
Q_{i}=v\left[\frac{S_{i}-S^{*}}{S^{-}-S^{*}}\right]+(1-v)\left[\frac{R_{i}-R^{*}}{R^{-}-R^{*}}\right]
$$

$$
\begin{aligned}
& S^{*}=\operatorname{Mins}_{i} ; S^{-}=\operatorname{MaxS}_{i} \\
& R^{*}=\operatorname{MinR}_{i} ; R^{-}=\operatorname{MaxR}_{i}
\end{aligned}
$$

Step 6: Ranking the options

Options are sorted based on the values of $\mathrm{S}, \mathrm{R}$ and $\mathrm{Q}$ in three groups from small to large. The best option is to have the smallest Q; provided that the following two conditions are met:

Condition 1: If options $A_{1}$ and $A_{2}$ have the first and second ranking options among $m$, the following equation is established. 


$$
Q\left(A_{2}\right)-Q\left(A_{1}\right) \geq \frac{1}{m-1}
$$

Condition 2: Option $\mathrm{A}_{1}$ must be recognized as a top rank in at least one of the groups $\mathrm{R}$ and $\mathrm{S}$. If the first condition is not met, both options will be the best option. If the second condition is not met, option $\mathrm{A}_{1}$ and $\mathrm{A}_{2}$ are both selected as the top option.

\subsection{Results of Environmental Tests}

Results of Balarood River water quality analysis in selected station (Figure 3) showed that during the years 2010 to 2018, with the beginning of the construction phase, the total amount of dissolved solute (TDS) and the electrical conductivity of the water have been increased, so that the highest value of TDS and EC are 2005, $33 \mathrm{mg} / 1$ and 1083/4 (us/cm), respectively. According to the obtained values and based on the environment organization standards and FAO, water quality in this parameter is in an unfavorable situation for drinking, agriculture and aquaculture. Also, by comparing the measurement of BOD and COD with values of 6 to $8 \mathrm{mg} / 1$ and 18 to $28 \mathrm{mg} / 1$, respectively and their comparison with the standard values of the World Health Organization in the river was determined that are higher than allowed.

The maximum and minimum values of the total coliform parameter during the construction phase at the selected station were shown as $1033 \mathrm{ml} 100 \mathrm{MPN}$ and $534 \mathrm{ml} 100 \mathrm{MPN}$, respectively. According to Iranian standard, these values will be higher than the allowable limit. By reviewing the results of tests in year 2010 on some parameters of air pollution at the project execution site and comparing them with the standard of environment organization found that $\mathrm{CO}$ and $\mathrm{SO}_{2}$ levels were measured at most stations due to refueling and transportation of heavy machinery, inadequate ventilation in tunnels, etc., is higher than the specified standard (Figure 3).

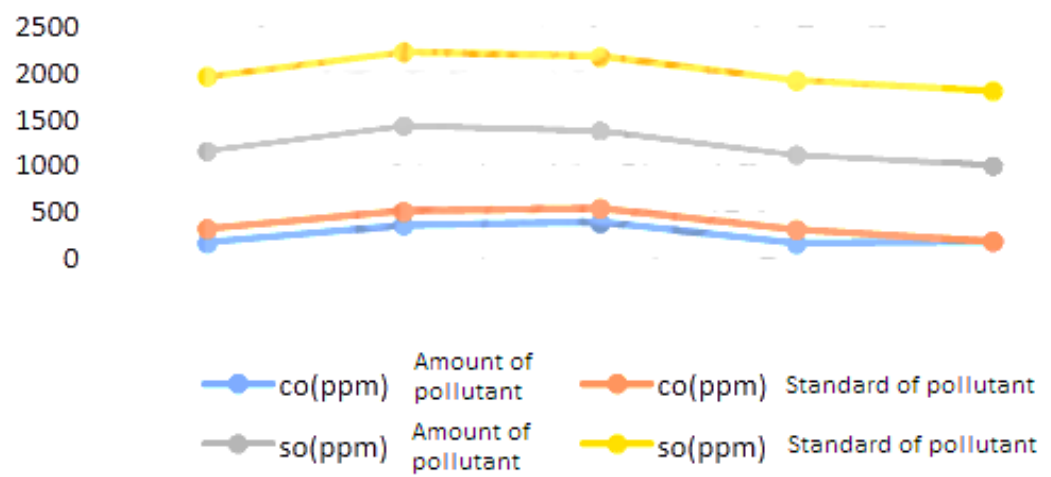

Figure3: Result of measuring $\mathrm{SO}_{2}$ and $\mathrm{CO}$ amount in selected dam stations

(Naddaf et al, 2017)

The results of noise pollution showed that the amount of noise is less than the allowable in residentialindustrial environments $(70 \mathrm{~dB})$ in all stations (Figure 4$)$. 


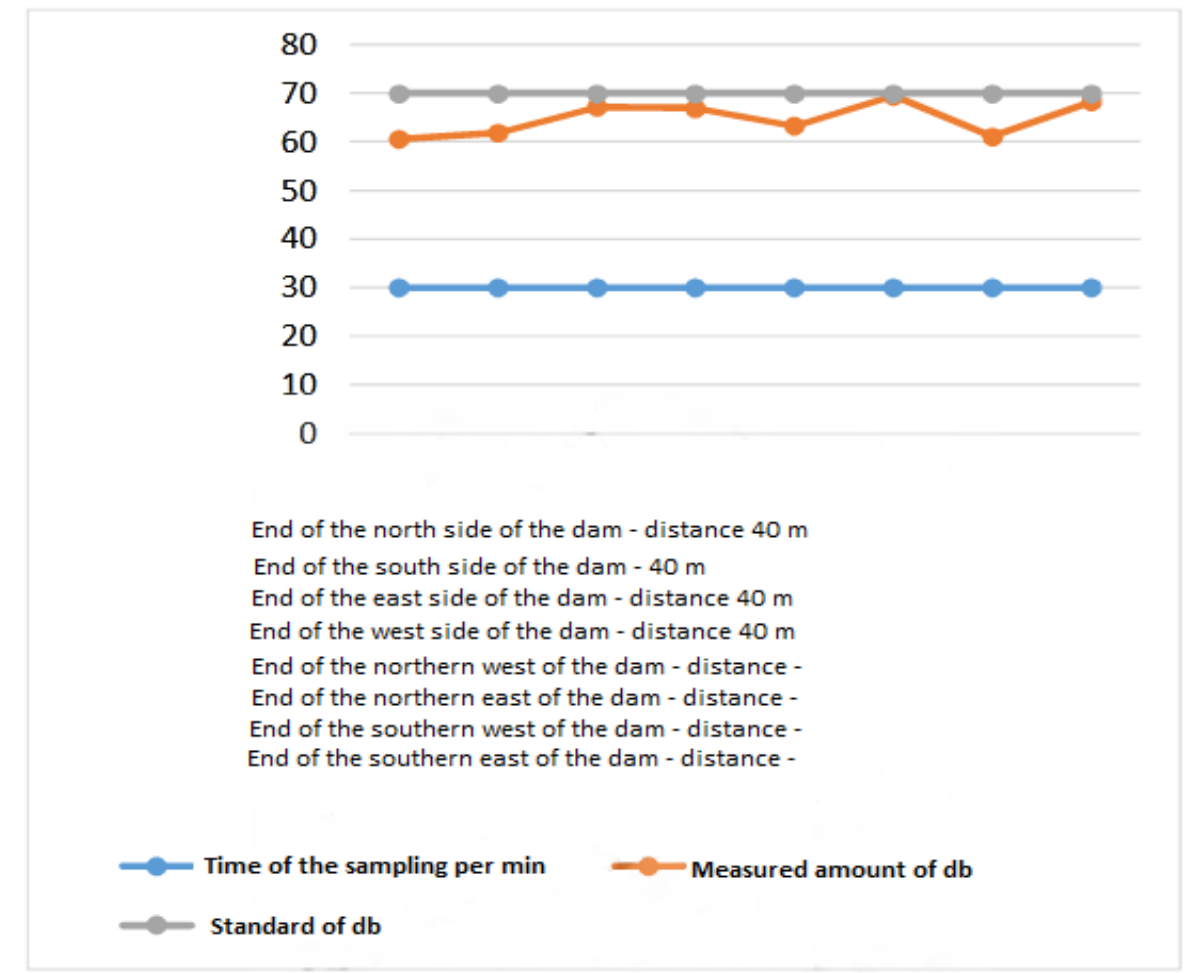

Figure 4: Results of the voice assessment at the destruction site of Balarood Dam

\subsection{Prioritization of Risk Assessment by EFMEA Method}

Based on the risk determination criteria, the scoring tables are prepared according to the method model separately. Scoring method parameters conducted according to field observations and interviews with experts HSE. After identifying the environmental risks of equipment and segmentation of created risks, the intensity columns, the probability of occurrence and the extent of pollution columns completed according to the EFMEA leveling tables and their RPN calculated.

Table 5. EFMEA leveling tables

\begin{tabular}{|c|c|c|c|c|c|c|c|}
\hline \multirow[t]{2}{*}{ Activity } & \multirow{2}{*}{$\begin{array}{c}\text { Potential } \\
\text { destructing } \\
\text { cases } \\
\text { (environmental } \\
\text { aspects) }\end{array}$} & \multirow{2}{*}{$\begin{array}{c}\text { Effect of } \\
\text { potential } \\
\text { destructing } \\
\text { (describing } \\
\text { environmental } \\
\text { consequences) }\end{array}$} & \multicolumn{5}{|c|}{ Assessment of environmental aspects } \\
\hline & & & Severity & $\begin{array}{l}\text { Probability } \\
\text { of } \\
\text { occurrence }\end{array}$ & $\begin{array}{l}\text { Extent } \\
\text { of } \\
\text { pollution }\end{array}$ & RPN & $\begin{array}{l}\text { Level } \\
\text { of the } \\
\text { risk }\end{array}$ \\
\hline $\begin{array}{c}\text { Accommodation of } \\
\text { personnel and } \\
\text { equipment, } \\
\text { exploitation of fuel } \\
\text { tanks, } \\
\text { transportation of } \\
\text { heavy machinery, } \\
\text { activity of } \\
\text { industrial units, } \\
\text { landfill sites, solid } \\
\text { waste and material } \\
\text { depot }\end{array}$ & $\begin{array}{c}\text { Insanitary } \\
\text { landfill and solid } \\
\text { waste, } \\
\text { evacuation of } \\
\text { vehicles } \\
\text { petroleum on the } \\
\text { road and or other } \\
\text { places to } \\
\text { perform } \\
\text { operations in } \\
\text { general nature, } \\
\text { contamination of } \\
\text { soil with waste }\end{array}$ & $\begin{array}{l}\text { Decreased } \\
\text { quality of soil } \\
\text { habitat }\end{array}$ & 4 & 4 & 4 & 64 & $\mathrm{M}$ \\
\hline
\end{tabular}




\begin{tabular}{|c|c|c|c|c|c|c|c|}
\hline & $\begin{array}{l}\text { such as engine } \\
\text { oil and diesel, } \\
\text { improper } \\
\text { disposal of } \\
\text { industrial and } \\
\text { sanitary waste of } \\
\text { project }\end{array}$ & & & & & & \\
\hline $\begin{array}{l}\text { Excavation and } \\
\text { embankment, } \\
\text { activity of repair } \\
\text { shops, location of } \\
\text { fuel storage, } \\
\text { material taking } \\
\text { operations from } \\
\text { loan sources, clear- } \\
\text { cutting, } \\
\text { destruction of } \\
\text { vegetates, } \\
\text { construction of } \\
\text { access roads }\end{array}$ & $\begin{array}{l}\text { Making shifts } \\
\text { and changes in } \\
\text { the horizon } \\
\text { constituent of the } \\
\text { soil that makes it } \\
\text { vulnerable } \\
\text { against the } \\
\text { erosion factors } \\
\text { such as rainfall, } \\
\text { removal of } \\
\text { vegetates; fuel } \\
\text { and oil leaks, } \\
\text { garbage } \\
\text { accumulation } \\
\text { and concreting in } \\
\text { the rainy season } \\
\text { and slurry } \\
\text { cement } \\
\text { distribution }\end{array}$ & $\begin{array}{l}\text { Intensification of } \\
\text { erosion and } \\
\text { geomorphology } \\
\text { change of the } \\
\text { region }\end{array}$ & 4 & 4 & 4 & 64 & $\mathrm{M}$ \\
\hline $\begin{array}{c}\text { Tunnel } \\
\text { construction and } \\
\text { construction of } \\
\text { contortioned dam, } \\
\text { material taking } \\
\text { operations from } \\
\text { loan sources }\end{array}$ & $\begin{array}{l}\text { In order to divert } \\
\text { water way and } \\
\text { constructing an } \\
\text { overflow } \\
\text { (maintenance a } \\
\text { volume of water) }\end{array}$ & $\begin{array}{l}\text { Changing the } \\
\text { natural river } \\
\text { regime and } \\
\text { decreasing } \\
\text { natural debi of } \\
\text { river in seasons } \\
\text { without rain }\end{array}$ & 4 & 5 & 5 & 100 & $\mathrm{M}$ \\
\hline $\begin{array}{c}\text { Excavation and } \\
\text { embankment, } \\
\text { activity of repair } \\
\text { shops, location of } \\
\text { fuel storage, } \\
\text { material taking } \\
\text { operations from } \\
\text { loan sources, } \\
\text { preparing } \\
\text { materials, clay } \\
\text { core operation, } \\
\text { constructing access } \\
\text { roads, equipping } \\
\text { camps and } \\
\text { personnel } \\
\text { accommodation, } \\
\text { construction of } \\
\text { tunnel and dam } \\
\text { body }\end{array}$ & $\begin{array}{l}\text { The entry of } \\
\text { sediments into } \\
\text { water sources, } \\
\text { increase of } \\
\text { suspended and } \\
\text { dissolved } \\
\text { materials load by } \\
\text { surface water } \\
\text { flow, direct } \\
\text { drainage of camp } \\
\text { sewage and } \\
\text { office locations } \\
\text { to acceptant } \\
\text { resources and } \\
\text { increasing BOD, } \\
\text { COD and fecal } \\
\text { coliforms of } \\
\text { river, reduction } \\
\text { of dissolved } \\
\text { oxygen in the } \\
\text { water of river }\end{array}$ & $\begin{array}{c}\text { Water pollution } \\
\text { of Balarood } \\
\text { River }\end{array}$ & 5 & 5 & 5 & 125 & $\mathrm{H}_{2}$ \\
\hline $\begin{array}{l}\text { Accommodation of } \\
\text { personnel and }\end{array}$ & $\begin{array}{l}\text { direct drainage } \\
\text { of camp sewage }\end{array}$ & $\begin{array}{c}\text { Decreased } \\
\text { quality of water }\end{array}$ & 4 & 4 & 5 & 80 & $\mathrm{H}_{1}$ \\
\hline
\end{tabular}




\begin{tabular}{|c|c|c|c|c|c|c|c|}
\hline $\begin{array}{c}\text { equipment, } \\
\text { excavation and } \\
\text { embankment of } \\
\text { drilling operation, } \\
\text { concreting, heavy } \\
\text { machinery } \\
\text { transport, activity } \\
\text { of industrial units, } \\
\text { landfill sites, solid } \\
\text { waste and material } \\
\text { depot }\end{array}$ & $\begin{array}{l}\text { and office } \\
\text { locations to } \\
\text { acceptant } \\
\text { resources, } \\
\text { landfill of } \\
\text { construction } \\
\text { materials and } \\
\text { garbage in rivers, } \\
\text { landfill of tunnel } \\
\text { and rock breaker } \\
\text { effluent } \\
\text { (industrial } \\
\text { effluent), taking } \\
\text { loan sources } \\
\text { from margin of } \\
\text { river, rock and } \\
\text { soil depot of soil } \\
\text { operation in } \\
\text { slopes dominant } \\
\text { to the river }\end{array}$ & habitat & & & & & \\
\hline $\begin{array}{c}\text { Activities of } \\
\text { personnel and staff } \\
\text { in region, drilling } \\
\text { and firefighting } \\
\text { activities }\end{array}$ & $\begin{array}{l}\text { Creating fear and } \\
\text { changing natural } \\
\text { behavior in birds }\end{array}$ & $\begin{array}{c}\text { Destroying } \\
\text { habitat of prey } \\
\text { birds loss of such } \\
\text { as small white- } \\
\text { fronted goose and } \\
\text { pond eagle }\end{array}$ & 3 & 5 & 4 & 60 & M \\
\hline $\begin{array}{c}\text { Removal of } \\
\text { vegetates, drilling } \\
\text { and firefighting } \\
\text { activities, } \\
\text { construction of } \\
\text { dam and } \\
\text { dependent } \\
\text { buildings and } \\
\text { access roads, } \\
\text { transportation of } \\
\text { heavy machinery }\end{array}$ & $\begin{array}{l}\text { Destruction of } \\
\text { the main habitat } \\
\text { of species, } \\
\text { especially } \\
\text { species that are } \\
\text { in the immediate } \\
\text { area of the } \\
\text { project, creating } \\
\text { fear and } \\
\text { changing natural } \\
\text { behavior in } \\
\text { animals }\end{array}$ & $\begin{array}{l}\text { Decreased habitat } \\
\text { security of } \\
\text { mammals such as } \\
\text { rams and sheep, } \\
\text { bears, leopards, } \\
\text { wolves, jackals } \\
\text { and foxes }\end{array}$ & 3 & 3 & 4 & 36 & $\mathrm{~L}$ \\
\hline
\end{tabular}

Table 6: Assessment results of the environmental risks of constructional phase by EFMEA method

\begin{tabular}{|c|c|c|c|c|c|c|c|}
\hline \multirow[t]{2}{*}{ Activity } & \multirow{2}{*}{$\begin{array}{c}\text { Potential } \\
\text { destructing } \\
\text { cases } \\
\text { (environmental } \\
\text { aspects) }\end{array}$} & \multirow{2}{*}{$\begin{array}{c}\text { Effect of } \\
\text { potential } \\
\text { destructing } \\
\text { (describing } \\
\text { environmental } \\
\text { consequences) }\end{array}$} & \multicolumn{5}{|c|}{ Assessment of environmental aspects } \\
\hline & & & Severity & $\begin{array}{c}\text { Probability } \\
\text { of } \\
\text { occurrence }\end{array}$ & $\begin{array}{l}\text { Extent of } \\
\text { pollution }\end{array}$ & RPN & $\begin{array}{l}\text { Level of } \\
\text { the risk }\end{array}$ \\
\hline $\begin{array}{l}\text { Excavation and } \\
\text { embankment } \\
\text { operations, } \\
\text { drilling and } \\
\text { blasting, } \\
\text { purification of } \\
\text { plant species in } \\
\text { the region }\end{array}$ & $\begin{array}{l}\text { Removal of } \\
\text { vegetates, } \\
\text { especially } \\
\text { native species, } \\
\text { improper depot } \\
\text { and landfill of } \\
\text { project waste, } \\
\text { especially solid }\end{array}$ & $\begin{array}{l}\text { Destruction of } \\
\text { natural image }\end{array}$ & 4 & 4 & 4 & 64 & M \\
\hline
\end{tabular}




\begin{tabular}{|c|c|c|c|c|c|c|c|}
\hline & $\begin{array}{c}\text { waste in } \\
\text { inappropriate } \\
\text { places }\end{array}$ & & & & & & \\
\hline $\begin{array}{l}\text { Excavation and } \\
\text { embankment, } \\
\text { activity of } \\
\text { repair shops, } \\
\text { location of fuel } \\
\text { storage, } \\
\text { material taking } \\
\text { operations from } \\
\text { loan sources, } \\
\text { preparing } \\
\text { materials, clay } \\
\text { core operation, } \\
\text { constructing } \\
\text { access roads, } \\
\text { equipping } \\
\text { camps and } \\
\text { personnel } \\
\text { accommodation } \\
\text { and } \\
\text { construction of } \\
\text { temporary } \\
\text { buildings }\end{array}$ & $\begin{array}{l}\text { Clear-cutting on } \\
\text { the surface of } \\
\text { natural } \\
\text { vegetates in the } \\
\text { region, lack of } \\
\text { suitable soil } \\
\text { with sufficient } \\
\text { depth due to } \\
\text { excavation of } \\
\text { the surrounding } \\
\text { lands, pollution } \\
\text { of the region's } \\
\text { soil habitat due } \\
\text { to the project } \\
\text { activities }\end{array}$ & $\begin{array}{l}\text { Reduce density } \\
\text { and removal of } \\
\text { plant species } \\
\text { such as Oak } \\
\text { and Astragalus }\end{array}$ & 2 & 4 & 4 & 48 & $\mathrm{~L}$ \\
\hline $\begin{array}{c}\text { Accommodation } \\
\text { of personnel } \\
\text { and equipment, } \\
\text { drilling } \\
\text { operations, } \\
\text { excavation and } \\
\text { embankment, } \\
\text { concreting } \\
\text { water diversion } \\
\text { system, activity } \\
\text { of industrial } \\
\text { units }\end{array}$ & $\begin{array}{l}\text { Change in river } \\
\text { watering, } \\
\text { sudden entry of } \\
\text { a significant } \\
\text { volume of } \\
\text { sewage to river } \\
\text { and ecological } \\
\text { imbalance due } \\
\text { to the entry of } \\
\text { sediments into } \\
\text { the river, } \\
\text { accumulation of } \\
\text { large amounts } \\
\text { of rotten } \\
\text { material and } \\
\text { sludge, creating } \\
\text { invasive species }\end{array}$ & $\begin{array}{l}\text { Population } \\
\text { decline and } \\
\text { fish habitat } \\
\text { (Carp fish } \\
\text { family) in the } \\
\text { Balarood } \\
\text { River, } \\
\text { suffocation of } \\
\text { fish babies and } \\
\text { burying their } \\
\text { eggs under the } \\
\text { bullet and } \\
\text { increase death } \\
\text { of aquatic } \\
\text { animals }\end{array}$ & 2 & 4 & 5 & 60 & $\mathrm{M}$ \\
\hline $\begin{array}{c}\text { Activities of } \\
\text { personnel and } \\
\text { equipment, } \\
\text { excavation and } \\
\text { embankment } \\
\text { operations, } \\
\text { concreting and } \\
\text { transportation } \\
\text { of heavy } \\
\text { machinery, } \\
\text { activity of } \\
\text { industrial units, } \\
\text { landfills for } \\
\text { solid waste And }\end{array}$ & $\begin{array}{c}\text { Improper } \\
\text { landfill of } \\
\text { industrial and } \\
\text { sanitary wastes, } \\
\text { making changes } \\
\text { due to erosive } \\
\text { factors because } \\
\text { of concreting in } \\
\text { the rainy } \\
\text { season, spread } \\
\text { slurry, cement, } \\
\text { evacuation of } \\
\text { industrial } \\
\text { effluent of }\end{array}$ & $\begin{array}{l}\text { Subsidence of } \\
\text { ancient hill } \\
\text { "Bord Panir" }\end{array}$ & 4 & 4 & 4 & 64 & $\mathrm{M}$ \\
\hline
\end{tabular}




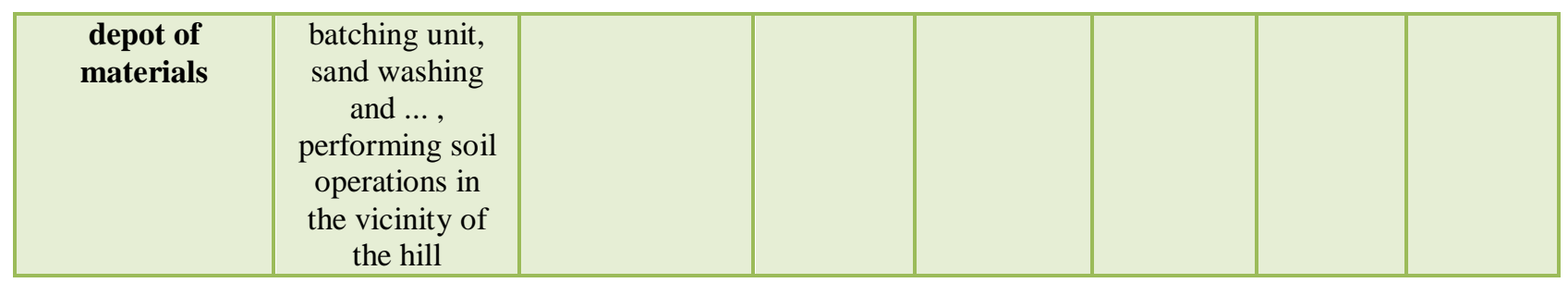

Continuation of Table 5: Results of environmental risk assessment of the constructional phase by EFMEA method As a result of calculating the risk priority number, the highest priority number is 125 and the lowest is 36 . Then, we performed statistical calculations according to the formulas presented in the materials and methods. So By determining the range of the category, we obtain the frequency of each category; in such a way that the number of risks in each of the ranges specified.

Table 7. Statistics obtained from calculating the risk priority number

\begin{tabular}{|c|c|}
\hline Number of data & $\mathbf{1 0}$ \\
\hline Number of categories & 4 \\
\hline The smallest risk priority number & 36 \\
\hline The largest risk priority number & 125 \\
\hline Length of the category & 22.25 \\
\hline
\end{tabular}

According to this classification, higher and equal risks to 104.75 specified as very high risk level (marked with the letter $\mathrm{H}_{1}$ ) and risks between 82.5 to 103.75 considered as high risk level (marked with the letter $\mathrm{H}_{2}$ ). Risks between 59.25 to 81.5 considered as an average and acceptable risk level (marked with the letter M) and less or equal risks to 58.25 were considered as low risk level (marked with the letter L). The results show that in environmental risk assessment, $20 \%$ of risks are at low level, $60 \%$ of risks are at average level, $10 \%$ of risks are at high level and $10 \%$ are at very high level.

\subsection{Analysis and Prioritization of Environmental Risks by VIKOR Method}

Environmental risks of Balarood Reservoir Dam in construction stage based on identified factors were determined. Then, they are based on three criteria (severity, probability of occurrence and extent of pollution) was assessed and prioritized using the VIKOR method. As the Figure 5 shows the river water pollution $\left(\mathrm{A}_{1}\right)$ with index of $0 / 2,0 / 5,0 / 8$ : $\mathrm{Qv}$ with weights of $0.700,1.000$ and 1.300 respectively, were the highest risk. Also, the lowest risk was the reduced security of mammal's habitat. Due to the length of construction operations and diversion of river flow and loss of natural vegetates, the concentration of solutes in river water has increased and it has led to a decrease in water quality for irrigation purposes. By reviewing the experiments performed during the years 2018-2020, we find that with the beginning of the construction phase, some parameters including the total soluble solids and the amount of electrical conductivity were increasing. Construction activities that increase the turbidity of river water, activities related to rock breakers, sand washers and batching unit. Due to poor evaporation pool performance, river water pollution has increased and led to the death of aquatic animals. Also, increased water pollution with toxic substances are due to activities such as refueling machines and spills petroleum materials from the refueling area or from under the machines to the river and also washing machinery and equipment are on its way. Construction activities increase the amount of particles in water, sediment and the destruction of benthic animals. This mode has caused imbalance in the ecological system of the aquatic environment and the reduction of aquatic habitat quality. 


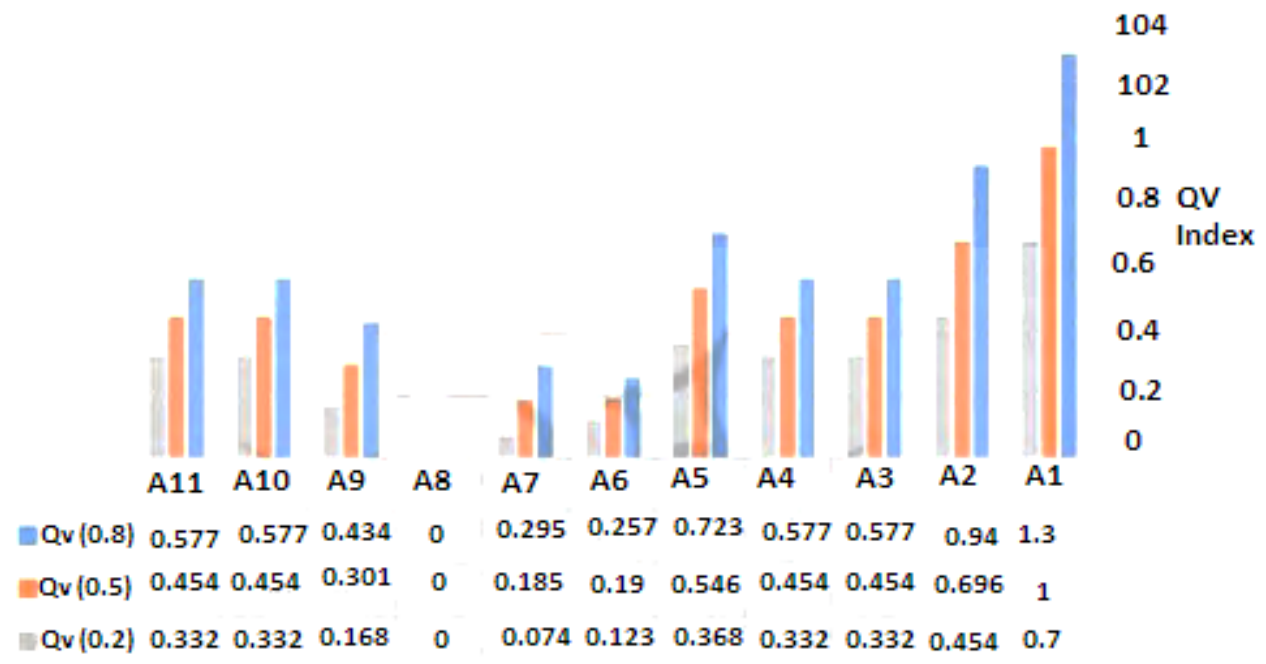

Figure5: The risk assessment results of Balarood Reservoir Dam in construction phase of postassessment studies

\section{CONCLUSIONS}

This study is conducted by the aims of providing a new model for environmental risk assessment of Balarood Dam in Khuzestan in construction phase of post-assessment studies of environmental impacts. According to the results and the methods used in this study, we conclude that the major risks occur in the physical and chemical environment. Also, the results of identifying environmental risks in the follow-up stage shows that the predicted effects in the EIA report of the Balarood Reservoir Dam are not been thoroughly and comprehensively reviewed. Based on the results of EFMEA method, "water pollution of river" with a risk priority number of 125 , is ranked first. This method also shows that $20 \%$ of the aspects are at low risk level, $60 \%$ are at average risk level, $10 \%$ are at high risk level and $10 \%$ are at very high risk level. According to the ranking, the risk of "water pollution of river" in the conditions of the above agreement, average and low $(0.2,0.5,0.8: \mathrm{Qv})$ is the first priority. After identify, quantify and prioritize the risks in the area, a risk response program is needed to present risks confrontation methods and appropriate opportunities before their occurrence. Intensity of identified risks with high priority through the implementation of environmental risk management plans is greatly reduced. Identifying, quantifying and prioritizing risks must be followed up by answering on risk management plans that address risk management methods before they occur. There are several ways to answer this; including risk elimination, risk reduction, risk conversion and risk acceptance. Management activities such as safety, health and environmental risk assessment can be implemented as a tool to achieve sustainable development goals. Failing to large engineering and construction projects have demonstrated the importance of risk management. Therefore, in according to the identified risks, avoidance and control of physical, chemical and biological pollution in the affected area and during the construction phase in the post-assessment stage of environmental impacts is one of the most important goals of environmental management.

\section{REFERENCES}

Chen, A., Sui, X., Wang, D. S., Liao, W. G., \& Tao, J. (2014). A brief review on post-project environmental appraisals of dam projects and recommendations for China. In Advanced Materials Research (Vol. 955, pp. 3451-3456). Trans Tech Publications Ltd. 
Dipper B. (2010). Monitoring and Post-auditing in Environmental Impact Assessment. A Review Jornal Environmental Planning and management.41: 731-747.

Wang, Q. G., et al.(2012). Environmental impact post-assessment of dam and reservoir projects. a review Procedia Environmental Sciences.13: 1439-1443.

Morales-Torres, A., Serrano-Lombillo, A., Escuder-Bueno, I., \& Altarejos-García, L. (2016). The suitability of risk reduction indicators to inform dam safety management. Structure and Infrastructure Engineering. 12(11). 1465-1476.

Shayna, S., \& Karam, A. (2017). River morphological changes analysis caused by Taleqan Dam counteraction-based on remote sensing time deferential data. The Journal of Spatial Planning. 21(2), 243263.

Raei, R., \& Jahromi, M. (2020). Portfolio optimization using a hybrid of fuzzy ANP, VIKOR and TOPSIS. Management Science Letters, 2(7), 2473-2484.

Wang Y, Zhang X, Zhang H, Lu Y, Huang H, Dong X, Chen J, Dong J, Yang X, Hang H, Jiang Wang,y., Zhang,X.,Zhang,h.,Lu,y.,Huang,Dong,X,.Chen,J,. $\quad$ Dong,J,.Hang,H,.Jianga,J,..(2012).Coiled-coil networking shapes cell molecular machinery. Mol Biol Cell 23(19):3911-22.

Samaras Katherine, Crawford John D., Draper Brian, Trollor Julian N., Brodaty Henry, Perminder S. Sachdev. (2020).Response to Comment on Samara et al. Metformin Use Is Associated With Slowed Cognitive Decline and Reduced Incident Dementia in Older Adults With Type 2 Diabetes. The Sydney Memory and Ageing Study. Diabetes Care.43:2691-2701.

Gati, A, Danielsson Gunnarsson, Häggqvist, B, Fredriksson. (2012). Bent Spine Syndrome: A Phenotype of Dysferlinopathy or a Symptomatic DYSF Gene Mutation Carrier. Bent Spine Syndrome.300-302.

Naddaf, S, Heidari, A.(2017).The Relationship Between Marital Intimacy and Quality of Life.Indian Journal of Public Health Research and Development 8(4):63. 